\title{
THE EFFECT OF INTRINSIC SOIL PROPERTIES ON SOIL QUALITY ASSESSMENTS ${ }^{(1)}$
}

\author{
Alessandro Samuel-Rosa ${ }^{(2)}$, Ricardo Simão Diniz Dalmolin ${ }^{(3)}$, Pablo Miguel ${ }^{(4)}$, Jovani \\ Zalamena $^{(5)}$ \& Deborah Pinheiro Dick ${ }^{(6)}$
}

\begin{abstract}
SUMMARY
The assessment of soil quality is based on indicators and indices derived from soil properties. However, intrinsic soil properties may interfere with other soil properties that vary under different land uses and are used to calculate the indices. The aim of this study was to assess the extent to which intrinsic soil properties (clay and iron oxide contents) explain variable soil properties (sum of bases, potential acidity, organic carbon, total porosity, and bulk density) under different land uses (native forest, no-tillage and conventional agriculture) on small family farms in Southern Brazil. The results showed that the five properties evaluated can be included in soil quality assessments and are not influenced by the clay and iron oxide contents. It was concluded that for little weathered 1:1 and 2:1 phyllosilicate rich-soils, if the difference between the maximum and the minimum clay content under the different land uses is less than about $200 \mathrm{~g} \mathrm{~kg}^{-1}$ and the iron oxide content less than about $15 \mathrm{~g} \mathrm{~kg}^{-1}$, the physico-chemical soil properties in the surface layer are determined mostly by the land use.
\end{abstract}

Index terms: soil quality, family farms, ANCOVA, spurious correlation.

\section{RESUMO: EFEITO DE PROPRIEDADES INTRÍNSECAS DO SOLO EM AVALIAÇÕES DE QUALIDADE DO SOLO}

A avaliação da qualidade do solo depende do uso de indicadores e índices construídos com as propriedades dele. Entretanto, essas propriedades podem variar entre tipos de uso do

(1) Received for publication on January 20, 2012 and approved on May 8, 2013.

(2) Doctoral student, Pos-graduation in Agronomy - Soil Science, Rio de Janeiro Rural Federal University. BR 465, Km 7, Zona Rural. CEP 23890-000 Seropédica (RJ), Brazil. CNPq scholarship. E-mail: alessandrosamuel@yahoo.com.br

(3) Professor, Soil Science Departament, Santa Maria Federal University - UFSM. Av. Roraima, 1000, Camobi. CEP 97105-900 Santa Maria, RS. CNPq grantee. E-mail: dalmolinrsd@gmail.com

(4) Professor, College of Agronomy Eliseu Maciel, Pelotas Federal University. Campus Universitário, s/n. CEP 96010-900 Pelotas (RS), Brazil. E-mail: tchemiguel@yahoo.com.br

(5) Pos Doctoral student, Pos-graduation in Soil Science, UFSM. FAPERGS scholarship. E-mail: jovanizalamena@yahoo.com.br

(6) Professor, Chemistry Institut, Rio Grande do Sul Federal University. Av. Paulo Gama, 110, Bairro Farroupilha. CEP 90040060 Porto Alegre (RS), Brazil. CNPq grantee. E-mail: debby.dick@gmail.com 


\begin{abstract}
solo, bem como interferir nas propriedades do solo usadas para construir os índices. Objetivouse com este estudo determinar a capacidade de propriedades intrínsecas do solo (teor de argila e óxido de ferro) para explicar as propriedades variáveis (soma de bases, acidez potencial, carbono orgânico, porosidade e densidade) em diferentes usos do solo (floresta nativa, plantio direto e agricultura convencional) em pequenas propriedades familiares no sul do Brasil. Os resultados evidenciaram que as cinco propriedades do solo estudadas podem ser incluídas em avaliações de qualidade e não são influenciadas pelo teor de argila e óxido de ferro. Sugeriu-se que, para solos pouco intemperizados, ricos em filossilicatos do tipo 1:1 e 2:1, se o teor de argila estiver em um intervalo de aproximadamente $200 \mathrm{~g} \mathrm{~kg}^{-1}$ e o de óxido de ferro for menor que aproximadamente $15 \mathrm{~g} \mathrm{~kg}^{-1}$, o uso do solo é o maior fator para controlar as propriedades físicoquímicas da camada superficial do solo.
\end{abstract}

Termos de indexação: qualidade do solo, agricultura familiar, ANCOVA, correlação espúria.

\section{INTRODUCTION}

The clearing of natural vegetation for agriculture leads to alterations in soil properties and, in several cases, to environmental degradation (Bewket \& Stroonijdeb, 2003; Muniz et al., 2011). This phenomenon calls for a concept of soil quality, which is the capacity of a soil to function within the limits of an ecosystem, interacting positively with the environment external to that ecosystem (Larson \& Pierce, 1991). A soil with good quality fulfils a number of functions (carbon storage, water reservoir, nutrient cycling, growth medium, among others), while simultaneously protecting other environmental components and sustaining human health (Doran \& Parkin, 1994). In this sense, assessing the soil quality is one of the main tasks of soil scientists (Basher, 1997).

However, in many regions there is still a lack of studies on soil quality (Reichert et al., 2003). One of these is the hillslope area of central Rio Grande do Sul (RS), Brazil, with mostly small family farms. These areas were first settled in the late XIX century by European immigrants, when native vegetation was replaced by agriculture. Today, farming is based on the integration of crop and livestock. There is little investment in machinery and fertilizers because of the complex topography, thin soils, small property sizes and low income of the farmers. On the other hand, higher-income farms with deeper soils and better road access adopted new and more intensive agricultural practices and activities, requiring investments in machinery and fertilizers. But soil conservation practices are insufficient, characterizing unsustainable agriculture and increasing the potential of land degradation (Samuel-Rosa et al., 2011).

The soil quality assessment has to be based on the use of indicators and indices that reflect soil processes, integrate different soil properties and are sensitive to environmental changes (Doran \& Parkin, 1994). Many soil properties can be included in such soil quality indices (Larson \& Pierce, 1991; Doran \& Parkin, 1994; Islam \& Weil, 2000; Geissen \& Guzman, 2006; Clemens et al., 2010). However, the heterogeneous character of soils must also be taken into consideration: intrinsic soil properties such as particlesize distribution and the type and content of oxides may vary among land uses. This variation can have a pronounced effect on the soil properties used to develop indices of soil quality (Miralles et al., 2009), hampering the evaluation of the true effect of land use. The aim of this study was to assess the extent to which intrinsic soil properties (clay and iron oxide contents) explain variable soil properties (sum of bases, potential acidity, organic carbon, total porosity, and bulk density) under different land uses (native forest, no-tillage and conventional agriculture) on small family farms in Southern Brazil.

\section{MATERIAL AND METHODS}

The data used in this study were measured on small family farms in the hillslope areas of central Rio Grande do Sul (RS), Brazil. The local topography is complex, with a relief ranging from undulated to mountainous. The altitude varies between 240 and $450 \mathrm{~m}$ asl. The climate is classified as Cfa (humid subtropical climate without a defined dry season), with a mean annual temperature of $19.2{ }^{\circ} \mathrm{C}$ and mean annual pluvial precipitation of $1,708 \mathrm{~mm}$, quite well distributed throughout the year (Maluf, 2000). Geologically, the area consists predominantly of igneous rocks. The natural vegetation (Atlantic semideciduous forest) is dominated by Patagonula americana, Parapiptadenia rigida, Myrocarpus frondosus, Cordia trichotoma, Cedrela fissilis, Apuleia leiocarpa and Luehea divaricata.

Three land uses were studied:

- native forest: nearly all areas under native forest today had been used for agriculture in the past century. European immigrants cleared the original native forest in the late XIX century and practiced conventional agriculture for several decades. Since the $1970 \mathrm{~s}$, areas with shallow $(<50 \mathrm{~cm})$ and stony soils were gradually abandoned, allowing the regrowth of native vegetation;

- no-tillage: >20 years of conventional agriculture cultivation of potato, Solanum tuberosum - followed 
by 4 years of no-tillage - soybean, Glycine $\max$, and ryegrass, Lolium multiflorum;

- conventional agriculture: $>20$ years of conventional agriculture - mayze, Zea mays, and ryegrass.

The soils are little weathered. Leptosols prevail in native forest and Acrisols in agricultural areas. The mineralogical assemblage of both soil types is similar. The soil clay mineral kaolinite $(\mathrm{Kt})$, common in Southern Brazil, is predominant (Kämpf \& Klamt, 1978). Besides, other clay minerals were identified, e.g., cristobalite, disordered kaolinite or halloysite or both, and hydroxy-Al interlayered 2:1 phyllosilicates (Kämpf \& Klamt, 1978; Dalmolin et al., 2006). There is evidence for the occurrence of a small amount of hematite. The soils vary in texture and differ significantly in clay and iron oxide contents (Table 1).

Nine disturbed and undisturbed soil samples were collected from two layers $(0-10$ and $10-20 \mathrm{~cm})$ for each land use, to determine the intrinsic soil properties clay and iron oxide contents (Table 1). The clay content was assessed by the pipette method (Kilmer \& Alexander, 1949), and total free iron oxide $\left(\mathrm{Fe}_{\mathrm{DCB}}\right)$ extracted by hot dithionite-citrate-bicarbonate (Mehra \& Jackson, 1960). The variable soil properties potential acidity, sum of bases ( $\mathrm{sum}$ of $\mathrm{Ca}^{2+}, \mathrm{Mg}^{2+}$ and $\mathrm{K}^{+}$), organic carbon, bulk density, and porosity were analyzed. Potential acidity $(\mathrm{H}+\mathrm{Al})$ was determined by titration with $\mathrm{NaOH}$ after extraction with $0.5 \mathrm{~mol} \mathrm{~L}^{-1}$ $\mathrm{Ca}\left(\mathrm{CH}_{3} \mathrm{COO}\right)_{2} \cdot \mathrm{H}_{2} \mathrm{O}$ solution at $\mathrm{pH}$ 7.0-7.1; $\mathrm{Ca}^{2+}$ and $\mathrm{Mg}^{2+}$ were quantified by atomic absorption after $1.0 \mathrm{~mol} \mathrm{~L}^{-1} \mathrm{KCl}$ extraction; $\mathrm{K}^{+}$was quantified by flame atomic emission spectrometry after extraction with Mehlich-1 solution (Mehlich, 1953); and organic carbon was determined by titration with $\mathrm{Fe}\left(\mathrm{NH}_{4}\right)_{2}\left(\mathrm{SO}_{4}\right)_{2} \cdot 6 \mathrm{H}_{2} \mathrm{O}$ after wet digestion with $0.2 \mathrm{~mol} \mathrm{~L}^{-1} \mathrm{~K}_{2} \mathrm{Cr}_{2} \mathrm{O}_{7}$ solution (Yeomans \& Bremner, 1988). All methods were described by Tedesco et al. (1995) and Donagema et al. (2011).

Statistical analysis was performed in the $R$ environment (R Core Team, 2013) using frequency histograms, cumulative frequency distribution graphs, and the Cullen and Frey graph to test data normality (Delignette-Muller et al., 2010; R Core Team, 2013). The homogeneity of variances among land uses was tested using box plots, standard deviations and Bartlett's Test (Bartlett, 1954; Webster, 2001). The distribution of the intrinsic soil properties was normal in both depth ranges. But for some variable soil properties (potential acidity and organic carbon in the upper, sum of bases in the lower layer) skewed distribution and heteroscedasticity were observed. Logarithmic transformation was used to achieve normality and stabilize the variances. The transformations altered the correlations between soil properties. The differences between dependent correlations (before and after transformation) were not significant at $5 \%$ probability of a type I error using Williams's Test (Steiger, 1980; Revelle, 2012). To test the hypothesis that the intrinsic soil properties were the same for all three land uses, we used ANOVA (analysis of variance) and analyzed the results by Fisher's LSDs (least significant differences) for means separation at a probability of $5 \%$ of committing a type I error (Fisher, 1951; Webster, 2007). To test the effect of clay and iron oxide content on variable soil properties, we used ANCOVA (analysis of covariance)

Table 1. Intrinsic soil properties in two depth ranges under three land uses (conventional agriculture, notillage and native forest)

\begin{tabular}{|c|c|c|c|c|c|}
\hline Land use & Soil order ${ }^{1}$ & Soil depth & Texture & Clay & $\mathbf{F} \mathbf{e}_{\mathrm{DCB}}^{(4)}$ \\
\hline \multirow{5}{*}{$\begin{array}{l}0-10 \mathrm{~cm} \\
\text { Conventional }\end{array}$} & \multicolumn{3}{|c|}{$\mathrm{m}$} & \multicolumn{2}{|c|}{$\mathrm{g} \mathrm{kg}^{-1}$} \\
\hline & \multicolumn{5}{|l|}{ Haplic Acrisol (Alumic, } \\
\hline & Hyperdystric, Siltic, Chromic) ${ }^{(1)}$ & $>1.0$ & Silty clay loam & $354( \pm 12)$ & $10.16( \pm 0.19)$ \\
\hline & Oxic Humudept ${ }^{(2)}$ & & & & \\
\hline & Cambissolo Háplico alumínico úmbrico ${ }^{(3)}$ & & & & \\
\hline No-tillage & As above $\mathrm{e}^{(1)}$ & $>1.0$ & Silty clay loam & $282( \pm 10)$ & $8.75( \pm 0.17)$ \\
\hline \multirow[t]{5}{*}{ Native forest } & Hyperskeletic Leptosol (Dystric) ${ }^{(1)}$ & \pm 0.40 & Silt loam & $240( \pm 16)$ & $8.95( \pm 0.17)$ \\
\hline & Lithic Udorthents $^{(2)}$ & & & & \\
\hline & Neossolo Litólico & & & & \\
\hline & distro-úmbrico fragmentário ${ }^{(3)}$ & & & & \\
\hline & & & $5 \% \operatorname{LSD}^{(5)}$ & 37 & 0.52 \\
\hline \multicolumn{6}{|l|}{$10-20 \mathrm{~cm}$} \\
\hline Conventional & & & Silty clay & $449( \pm 28)$ & $11.77( \pm 0.43)$ \\
\hline No-tillage & & & Silt loam & $261( \pm 16)$ & $9.15( \pm 0.29)$ \\
\hline \multirow[t]{2}{*}{ Native forest } & & & Silty clay loam & $317( \pm 21)$ & $8.69( \pm 0.24)$ \\
\hline & & & $5 \%$ LSD & 66 & 0.96 \\
\hline
\end{tabular}

(1) IUSS-WRB (2006), ${ }^{(2)}$ Soil Survey Staff (2010), ${ }^{(3)}$ Santos et al. (2006); ${ }^{(4)} \mathrm{Fe}_{\mathrm{DCB}}$ : dithionite-extracted iron; ${ }^{(5)}$ LSD: Fisher's least significant difference at $5 \%$ (error degrees of freedom $=24$ ). 
when the correlation between soil properties was significant at $5 \%$ probability of a type I error in the Student's t-tests (Revelle, 2012). The relation between intrinsic and variable soil properties was also analyzed using partial correlations (Revelle, 2012) and scatterplots with a $95 \%$ confidence interval of a linear fit (Wickham, 2009; R Core Team, 2013). Tables and plots are presented according to the latest international recommendations for statistical results in soil science (Webster, 2001; Webster, 2007). Soil data and $\mathrm{R}$ scripts are freely available at $<\mathrm{http}: / /$ www.soil-scientist.net>.

\section{RESULTS}

The intrinsic soil properties were correlated with the variable soil properties (Table 2). Potential acidity is significantly correlated with clay and $\mathrm{Fe}_{\mathrm{DCB}}$ in both layers, but the correlation was strongest in the subsurface. However, the partial correlation $(r)$ between potential acidity and $\mathrm{Fe}_{\mathrm{DCB}}$, when the clay constant was fixed, $r$ was only 0.252 in the surface and 0.084 in the subsurface layer. Besides, the data points were not evenly distributed in the $95 \%$ confidence interval of the mean in the scatterplots (Figure 1), that is, they were stratified according to the land use. Removing data of any land use significantly altered the correlation between soil properties. An exception is the correlation of clay with potential acidity for the subsurface. The ANCOVA table (Table 3) showed that the effect of $\mathrm{Fe}_{\mathrm{DCB}}$ on potential acidity was not significant. Clay also played a minor role, accounting for no more than $5 \%$ of the total variance, while land use accounted for more than $80 \%$ in both layers.

Sum of bases was negatively correlated with clay and $\mathrm{Fe}_{\mathrm{DCB}}$ content (Table 2). However, the partial correlation of the sum of bases with $\mathrm{Fe}_{\mathrm{DCB}}$ in the 0-10

Table 2. Linear correlation coefficient ${ }^{(1)}$ of intrinsic soil properties with indicators of soil quality in two depth ranges under three land uses (conventional agriculture, no-tillage and native forest)

\begin{tabular}{lccccc}
\hline \multirow{2}{*}{$\begin{array}{l}\text { Soil quality } \\
\text { indicator }\end{array}$} & \multicolumn{4}{c}{ Depht } \\
\cline { 2 - 3 } & \multicolumn{2}{c}{$\mathbf{0 - 1 0} \mathbf{~ c m}$} & & $\mathbf{1 0 - 2 0} \mathbf{~ c m}$ \\
\cline { 2 - 3 } \cline { 5 - 6 } & $\mathbf{C l a y}$ & $\mathbf{F e}_{\mathbf{D C B}}{ }^{(2)}$ & & Clay & $\mathbf{F e}_{\mathbf{D C B}}$ \\
\hline Potential acidity & 0.382 & 0.418 & & 0.766 & 0.643 \\
Sum of bases & -0.533 & -0.524 & & -0.463 & -0.250 \\
Organic carbon & -0.659 & -0.376 & & -0.347 & -0.464 \\
Bulk density & 0.554 & 0.220 & & -0.029 & 0.265 \\
Porosity & -0.593 & -0.256 & & 0.126 & -0.185 \\
\hline
\end{tabular}

(1) Correlation coefficients with $r \geq 0.380$ are significant in $95 \%$ of the cases $(n=27) .{ }^{(2)}$. $\mathrm{Fe}_{\mathrm{DCB}}$ : dithionite-extracted iron. cm layer at a fixed clay content was only $r=-0.295$. In addition, data points were not evenly distributed in the $95 \%$ confidence interval of the mean in the scatterplots (Figure 1). Again, removing data from any land use significantly altered the correlation between soil properties. The ANCOVA results (Table 3) showed a minor effect of the clay content on the sum of bases in the surface layer $(10 \%$ of the total variance), and no effect in the subsurface layers.

Organic carbon correlated negatively with clay content in the $0-10 \mathrm{~cm}$ layer and with $\mathrm{Fe}_{\mathrm{DCB}}$ in the 10-20 cm layer (Table 2). However, data points were stratified in the scatterplots according to land use (Figure 1). The ANCOVA (Table 3) showed a minor effect of clay on soil organic carbon, accounting for less than $5 \%$ of the total variance. Moreover, the effect of $\mathrm{Fe}_{\mathrm{DCB}}$ was not significant compared to the effect of the land uses, which accounted for $80 \%$ of the total variance in the $0-10 \mathrm{~cm}$ layer and for $36 \%$ in the 10 $20 \mathrm{~cm}$ layer.

Bulk density was positively correlated with clay content in the surface layer (Table 2). However, some degree of stratification of data points according to the land use was identified in the scatterplot (Figure 1). Besides, few data points were within the $95 \%$ confidence interval of the mean. The ANCOVA showed that clay had no significant effect on soil bulk density (Table 4). Land use accounted for more than $80 \%$ of the total variance.

Porosity was negatively correlated with clay content (Table 2). In the scatterplot, we observed a marked stratification of data points according to the land use (Figure 1). Thus, removing data from any land use significantly altered the correlations between soil properties. The ANCOVA showed that clay did not affect soil porosity and that land use accounted for more than $85 \%$ of the total variance (Table 4 ).

\section{DISCUSSION}

Scatterplots and ANCOVA were essential to identify the true correlations between soil properties. The use of correlation coefficients alone would have resulted in a misinterpretation of the relations between soil properties and led to an overestimation of the effect of intrinsic soil properties. In this study, all correlations were statistically significant, however not meaningful, e.g., the correlation between clay content and sum of bases. Phyllosilicate rich-soils, such as the Leptosols and Acrisols studied here, are known to have a net negative charge (Essington, 2004). In this case, a positive correlation would be expected between sum of bases and clay content. However, conversely, we observed a spurious correlation. An accidental correlation is one to which no "natural" causal interpretation can be applied (Haig, 2003). In this study, the spurious correlation observed was a result 

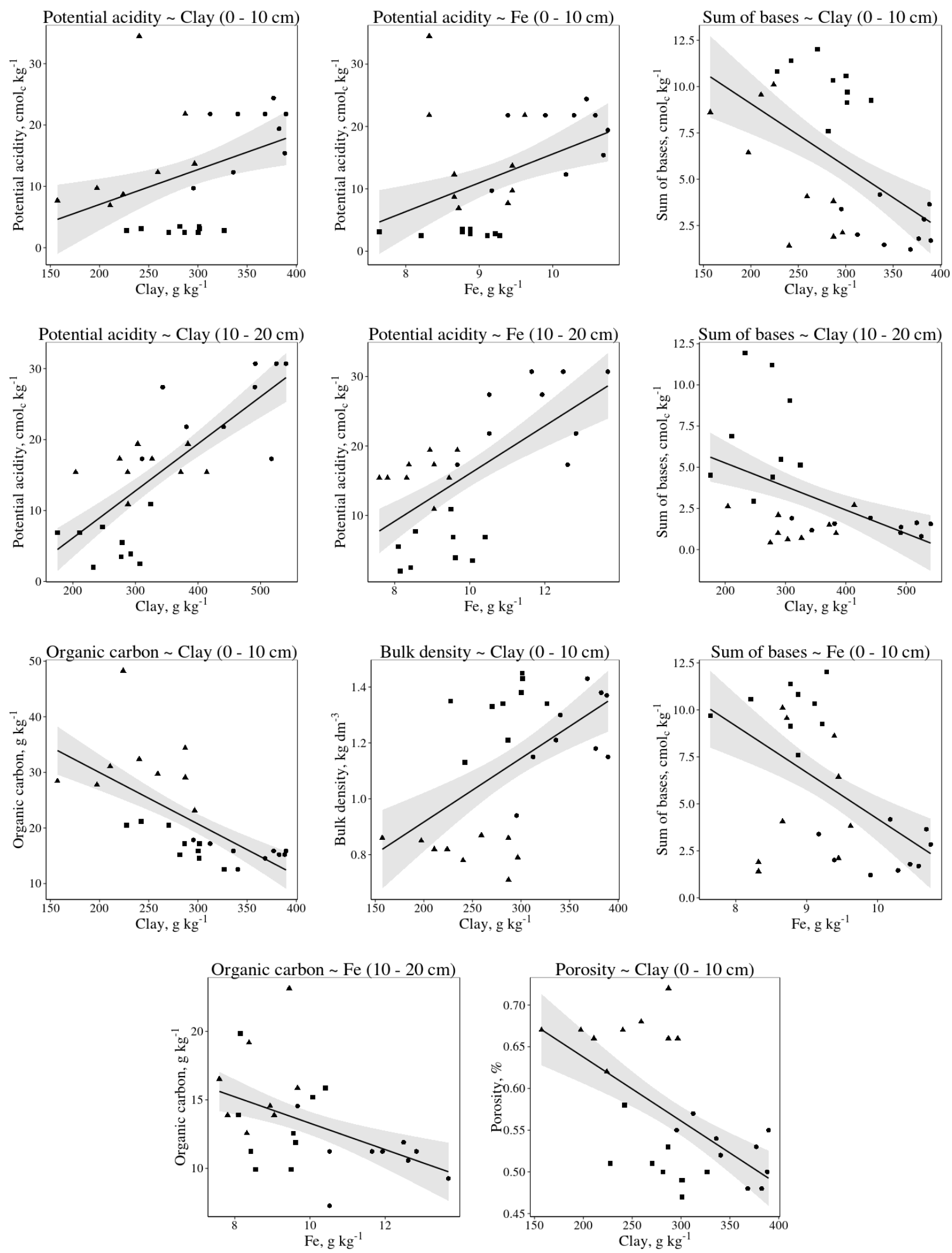

Figure 1. Linear relation of intrinsic soil properties (clay and iron oxide) with indicators of soil quality (potential acidity, organic carbon, sum of bases, bulk density, and porosity) in two depth ranges (0-10 and 10-20 cm) under three land uses $(\bullet$ Conventional agriculture, $\bullet$ No-tillage, $\triangle$ Native forest), with the $95 \%$ confidence interval in gray. 
Table 3. Analysis of covariance statistics of soil potential acidity $(\mathrm{H}+\mathrm{Al})$, sum of bases and soil organic carbon (SOC) for three land uses (conventional agriculture, no-tillage and native forest)

\begin{tabular}{|c|c|c|c|c|c|c|}
\hline \multirow{2}{*}{ Source of variation } & \multicolumn{2}{|c|}{$\mathrm{H}+\mathrm{Al}^{(\mathbf{1})}$} & \multicolumn{2}{|c|}{ Sum of bases ${ }^{(2)}$} & \multicolumn{2}{|c|}{ SOC $^{(1)}$} \\
\hline & $\begin{array}{l}\text { Degree of } \\
\text { freedom }\end{array}$ & $\begin{array}{c}\text { Mean } \\
\text { square }\end{array}$ & $\begin{array}{l}\text { Degree of } \\
\text { freedom }\end{array}$ & $\begin{array}{l}\text { Mean } \\
\text { square }\end{array}$ & $\begin{array}{l}\text { Degree of } \\
\text { freedom }\end{array}$ & $\begin{array}{c}\text { Mean } \\
\text { square }\end{array}$ \\
\hline \multicolumn{7}{|l|}{$0-10 \mathrm{~cm}$} \\
\hline Treatment & 4 & 4.5426 & 4 & 78.016 & 3 & 0.88583 \\
\hline Land use & 2 & $8.5959 * * *$ & 2 & $133.384^{* * *}$ & 2 & $1.27740 * * *$ \\
\hline Clay & 1 & $0.9032 * *$ & 1 & $40.027 * *$ & 1 & 0.10271 \\
\hline $\mathrm{Fe}_{\mathrm{DCB}}{ }^{(3)}$ & 1 & 0.0753 & 1 & 5.269 & - & - \\
\hline Residual & 22 & 0.1081 & 22 & 3.282 & 23 & 0.02388 \\
\hline $\begin{array}{l}\text { Total } \\
10-20 \mathrm{~cm}\end{array}$ & 26 & 0.7904 & 26 & 14.780 & 26 & 0.12334 \\
\hline Treatment & 4 & 440.96 & 3 & 5.0603 & 3 & 37.500 \\
\hline Land use & 2 & $856.26 * * *$ & 2 & $7.5880 * * *$ & 2 & $56.191^{* *}$ \\
\hline Clay & 1 & 40.67 & 1 & 0.0050 & - & - \\
\hline $\mathrm{Fe}_{\mathrm{DCB}}$ & 1 & 10.66 & - & - & 1 & 0.119 \\
\hline Residual & 22 & 14.36 & 23 & 0.2583 & 23 & 8.788 \\
\hline Total & 26 & 79.99 & 26 & 0.8124 & 26 & 12.101 \\
\hline
\end{tabular}

(1) Data of the $0-10 \mathrm{~cm}$ layer transformed to the logarithmic scale; ${ }^{(2)}$ Data of the $10-20 \mathrm{~cm}$ layer transformed to the logarithmic scale. ${ }^{(3)} \mathrm{Fe}_{\mathrm{DCB}}$ : dithionite-extracted iron. ${ }^{* *}$ and $* *: \mathrm{F}$ test significant at 1 and $0.1 \%$ level, respectively.

Table 4. Analysis of covariance statistics of soil bulk density and porosity for three land uses (conventional agriculture, no-tillage and native forest) in 0-10 cm depth

\begin{tabular}{lccccc}
\hline \multirow{2}{*}{ Source of variation } & \multicolumn{2}{c}{ Bulk density } & & \multicolumn{2}{c}{ Porosity } \\
\cline { 2 - 3 } \cline { 5 - 6 } & Degree of freedom & Mean square & & Degree of freedom & Mean square \\
\hline Treatment & 3 & 0.45281 & 3 & 0.046546 \\
Land use & 2 & $0.66565^{* * *}$ & 2 & $0.069048^{* * * *}$ \\
Clay & 1 & 0.02715 & 1 & 0.001542 \\
Residual & 23 & 0.01141 & 23 & 0.000866 \\
Total & 26 & 0.06234 & 26 & 0.006137 \\
\hline
\end{tabular}

Correlations between soil properties were significant only in the surface layer. ${ }^{*} *$ : F test significant at the $0.1 \%$.

of the accidental occurrence of the highest sum of bases and lowest clay content in soils under no-tillage on the one hand, and the lowest sum of bases and highest clay content in soils under conventional agriculture on the other hand. According to the land-use history, soils under no-tillage are periodically treated with high fertilization rates, while in soils under conventional cultivation, only a small part of the nutrients exported by crops is replaced. On the other hand, in soils under native forest the sum of bases is slightly higher than under conventional agriculture because there is no export of nutrients. Besides, soils under native forest are Leptosols, which means that the weathering was less intense than of Acrisols, resulting in less leaching of bases from the soil profile (Chesworth, 2008). Because of all these relations, the variation in the sum of bases in these soils is a result of the land-use history (and maybe soil type). Clay and iron oxide content have no major influence, suggesting that they are not relevant in the assessment of soil quality.
The correlation of intrinsic soil properties with organic carbon, bulk density and porosity were accidental as well. It is known that clay and iron oxides can play a positive role in organic carbon accumulation in soils (Dalmolin et al., 2006). We also expected a negative correlation of clay content with bulk density, in the same way as lower clay contents reduce soil porosity (Michelon et al., 2007). However, the correlation in the studied soils was opposite to the one expected. Similarly to the trend of the sum of bases, the variation observed in organic carbon, bulk density and porosity was mainly affected by the land-use history.

Only the correlation between intrinsic soil properties and potential acidity was as expected (Tan, 2010). However, despite the statistically significant correlations, ANCOVA showed that clay content had only a minor effect on potential acidity and that $\mathrm{Fe}_{\mathrm{DCB}}$ had none. The land use had the greatest effect on the potential acidity in both layers, as evidenced by the 
stratification of the points in the scatterplots. Once again there was an accidental correlation, where soils with lower clay content were under a land use (notillage) that reduced potential acidity. The soils under no-tillage were periodically limed. On the other hand, soils with higher clay content were under a land use (conventional agriculture) that induced the degradation of soil fertility. Under conventional agriculture, the soil was limed more than four years before sampling. In turn, soils under native forest were not fertilized or limed and consequently organic matter is the component with the greatest impact on availability of exchangeable aluminium (Silva et al., 2008) and thus on potential acidity. Since these soils have higher organic carbon content than soils under conventional agriculture, the potential acidity will be lower.

Our results showed that under the tested conditions, soil properties important for land use such as potential acidity, sum of bases, organic carbon, bulk density, and porosity are affected by the land use. They are efficient in reflecting land use and are little affected by intrinsic soil properties such as clay and iron oxide content, suggesting that they can be included in soil quality assessments. Our data also indicated that despite statistically significant differences in clay and iron oxide content among soils, these soil properties have no effect on the results of soil quality assessments. Webster (2001) previously stated that when a difference is considered statistically significant, it is not necessarily important or physically or biologically meaningful. Our findings and those of many other researchers agree with this statement. Mandal et al. (2010) studied Himalayan Entisols and Inceptisols with clay contents between 106 and $172 \mathrm{~g} \mathrm{~kg}^{-1}$ and found that soil management strongly influenced the soil quality indicators. Marzaioli et al. (2010) studied sandy loam and loam sandy Mediterranean soils (clay content $54-171 \mathrm{~g} \mathrm{~kg}^{-1}$ ) and also observed that any differences in soil quality could be attributed to differences in land use. Similar results were found by Schipper et al. (2010), who expected to find fewer changes in organic carbon after 40 years in Andisols in New Zealand than in other soil orders due to the remarkable capacity of allophane and imogolite to sequester and protect organic carbon (Parfitt, 2009). Miralles et al. (2009) found that clay and iron oxide contents in soil samples of Leptosols, Calcisols, Vertisols, Luvisols, Kastanozems, and Chernozems (clay content between 219 and $483 \mathrm{~g} \mathrm{~kg}^{-1}$ and $\mathrm{Fe}_{\mathrm{DCB}}$ content between 4.4 and $14.1 \mathrm{~g} \mathrm{~kg}^{-1}$ ) were weakly correlated with organic carbon $(r<0.26$, $p=0.05, n=68$ ). Percival et al. (2000) studied New Zealand soils (Andisols, Inceptisols, Ultisols, Mollisols, Oxisols, Alfisols, Spodosols, Entisols, Aridisols, and Ultisols) with clay contents from $38 \mathrm{~g} \mathrm{~kg}^{-1}$ to $329 \mathrm{~g} \mathrm{~kg}^{-1}$ and found that carbon contents correlated poorly with clay content across and within soil orders. According to the authors, the clay content accounted for only $1 \%$ of the variation in carbon content in both cases.
However, several studies have shown that intrinsic soil properties can control the expression of other soil properties. In the above-mentioned study, Miralles et al. (2009) observed a strong correlation of clay and iron oxide content with cation exchange capacity, porosity and bulk density. Likewise, Dieckow et al. (2009) compared a clay Ferralsol (clay: $711 \mathrm{~g} \mathrm{~kg}^{-1}$; $\mathrm{Fe}_{\mathrm{DCB}}: 87.6 \mathrm{~g} \mathrm{~kg}^{-1}$ ), a sandy clay Ferralsol (clay: $360 \mathrm{~g}$ $\mathrm{kg}^{-1} ; \mathrm{Fe}_{\mathrm{DCB}}: 48.3 \mathrm{~g} \mathrm{~kg}^{-1}$ ) and a sandy clay loam Acrisol (clay: $220 \mathrm{~g} \mathrm{~kg}^{-1} ; \mathrm{Fe}_{\mathrm{DCB}}$ : $11.8 \mathrm{~g} \mathrm{~kg}^{-1}$ ) and observed that clay and iron oxide contents were strongly correlated with organic carbon. According to Dieckow et al. (2009), in terms of organic carbon losses, the conversion of native vegetation to cropland is less harmful in clayey than in sandy soils, possibly because of a chemical and physical protection.

The inconsistency of the findings of different researchers shows the need for further research on the role of intrinsic soil properties in the control of the effect of land uses on soil properties included in soil quality assessments. Meanwhile, we can suggest that textural classes should not be used as isolated tools to describe the heterogeneous character of soils and to explain the effects of intrinsic soil properties on other chemical and physical soil properties. Our study shows that despite the soil classification in different texture classes, the clay content has no apparent effect on other chemical and physical properties. Whenever possible, the information on intrinsic soil properties should be used as a continuous (clay content) and not as a discrete variable (textural class). Therefore, ANCOVA becomes highly relevant in the assessment of the extent to which chemical and physical soil properties can be explained by intrinsic soil properties under different land uses and thus affect soil quality assessments. Future studies must focus on the identification and definition of clay and iron oxide content ranges and other oxides in soils that affect the behavior of soil chemical and physical properties used in soil quality assessments in different ways.

Finally, a general recommendation for studies on little weathered 1:1 and 2:1 phyllosilicate rich-soils with a similar mineralogy as in the soils of this study. If the difference between the maximum and the minimum clay content under different land uses is less than about $200 \mathrm{~g} \mathrm{~kg}^{-1}$ and the iron oxide content less than approximately $15 \mathrm{~g} \mathrm{~kg}^{-1}$, the physicochemical soil properties in the surface layer $(0-20 \mathrm{~cm})$ are determined mostly by the land use and history. The effect of intrinsic soil properties is negligible and only detectable in deeper layers $(>20 \mathrm{~cm})$, where management practices have less effect.

\section{CONCLUSIONS}

1. Organic carbon content, sum of bases, potential acidity, bulk density and porosity are easy measureable soil properties, reflect the land use and are little 
affected by intrinsic soil properties (clay and iron oxides). This suggests that they can be included in the assessment of the soil quality on small family farms.

2. Despite the classification of soils in different texture classes, intrinsic soil properties (clay and iron oxide contents) may have no effect on other chemical and physical soil properties. Whenever possible, information on intrinsic soil properties in soil quality assessments should be used as continuous rather than as discrete variables.

3. For little weathered $1: 1$ and 2:1 phyllosilicate rich-soils, if the difference between the maximum and the minimum clay content under different land uses is less than about $200 \mathrm{~g} \mathrm{~kg}^{-1}$ and the iron oxide content less than about $15 \mathrm{~g} \mathrm{~kg}^{-1}$, the physico-chemical soil properties in the surface layer are determined mostly by the land use.

\section{ACKNOWLEDGEMENTS}

We are grateful to Dr. Richard Webster, at the Rothamsted Research Centre, whose comments were decisive to improve our work. The authors gratefully acknowledge the support of the National Council for Scientific and Technological Development $(\mathrm{CNPq})$ and of the Research Support Foundation of the State of Rio Grande do Sul (FAPERGS) grants to the authors and financial support for this research.

\section{LITERATURE CITED}

BARTLETT, M.S. A note on the multiplying factors for various chi-squared approximations. J. Royal Statist. Soc. Series B., 16:296-298, 1954.

BASHER, L.R. Is pedology dead and buried? Aust. J. Soil Res., 35:979-994, 1997.

BEWKET, W. \& STROOSNIJDERB, L. Effects of agroecological land use succession on soil properties in Chemoga watershed, Blue Nile basin, Ethiopia. Geoderma, 111:8598, 2003.

CHESWORTH, W. Encyclopedia of earth sciences series. Dordrecht, Springer, 2008. 902p.

CLEMENS, G.; FIEDLER, S.; CONG, N.D.; van DUNG, N.; SCHULER, U. \& STAHR, K. Soil fertility affected by land use history, relief position, and parent material under a tropical climate in NW-Vietnam. Catena, 81:87-96, 2010.

DALMOLIN, R.S.; GONÇALVES, C.N.; DICK, D.P.; KNICKER, H.; KLAMT, E. \& KÖGEL-KNABNER, I. Organic matter characteristics and distribution in Ferralsol profiles of a climosequence in southern Brazil. Eur. J. Soil Sci., 57:644$654,2006$.
DELIGNETTE-MULLER, M.L.; POUILLOT, R.; DENIS, J.-B. \& DUTANG, C. Fitdistrplus: Help to fit of a parametric distribution to non-censored or censored data. Viena, $R$ Project, 2010. 29p.

DIECKOW, J.; BAYER, C.; CONCEIÇÃO, P.C.; ZANATTA, J.A.; MARTIN-NETO, L.; MILORI, D.B.M.; SALTON, J.C.; MACEDO, M.M.; MIELNICZUK, J. \& HERNANI, L.C. Land use, tillage, texture and organic matter stock and composition in tropical and subtropical Brazilian soils. Eur. J. Soil Sci., 60:240-249, 2009.

DONAGEMA, G.K.; CAMPOS, D.V.B.; CALDERANO, S.B.; TEIXEIRA, W.G. \& VIANA, J.H.M. Handbook of methods of soil analysis. Rio de Janeiro, Embrapa Solos, 2011. 230 p.

DORAN, J.W. \& PARKIN, T.B. Defining and assessing soil quality. In: DORAN, J.W.; COLEMAN, D.C.; BEZDICEK, D.F. \& STEWART, B.A., eds. Defining soil quality for a sustainable environment. Madison, Soil Sience Socienty of America, 1994. p.3-21.

ESSINGTON, M.E. Soil and water chemistry: An integrative approach. Boca Raton, CRC Press, 2004. 534p.

FISHER, R.A. The design of experiments. London, Oliver and Boyd, 1951. 248p.

HAIG, B.D. What is a spurious correlation? Underst. Stat., 2:125-132, 2003.

GEISSEN, V. \& GUZMAN, G.M. Fertility of tropical soils under different land use systems - a case study of soils in Tabasco, Mexico. Appl. Soil Ecol., 31:169-178, 2006.

ISLAM, K.R. \& WEIL, R.R. Soil quality indicator properties in mid-atlantic soils as influenced by conservation management. J. Soil Water Conserv., 55:69-78, 2000.

IUSS WORKING GROUP WRB - IUSS-WRB. World reference base for soil resources 2006. 2.ed. Roma, FAO, 2006. 132p.

KÄMPF, N. \& KLAMT, E. Mineralogy and genesis of Oxisols and Ultisols from the Northeastern region of the Sulriograndense Plateau. R. Bras. Ci. Solo, 2:68-73, 1978.

KILMER, V.J. \& ALEXANDER, L. Methods of making mechanical analyses of soils. Soil Sci., 68:15-24, 1949.

LARSON, W.E. \& PIERCE, F.J. Conservation and enhancement of soil quality. In: INTERNATIONAL WORKSHOP ON EVALUATION FOR SUSTAINABLE LAND MANAGEMENT IN THE DEVELOPING WORLD, Chiang Rai, 1991. Proceedings... Bangkok, International Board for Soil Research and Management, 1991. p.175-203.

MANDAL, D.; SINGH, R.; DHYANI, S. \& DHYANI, B. Landscape and land use effects on soil resources in a Himalayan watershed. Catena, 81:203-208, 2010.

MALUF, J. A new climatic classification for the state of Rio Grande do Sul, Brazil. R. Bras. Agrometeorol., 8:141-150, 2000.

MARZAIOLI, R.; D'ASCOLI, R.; PASCALE，R.D. \& RUTIGLIANO, F. Soil quality in a Mediterranean area of Southern Italy as related to different land use types. Appl. Soil Ecol., 44:205-212, 2010. 
MEHLICH, A. Determination of P, Ca, Mg, K, Na and $\mathrm{NH}_{4}$. Raleigh, North Carolina Soil Testing Division, 1953. p.195. (Não Publicado)

MEHRA, O.P. \& JACKSON, M.L. Iron oxide removal from soils and clays by a dithionite-citrate system buffered with sodium bicarbonate. In: NATIONAL CONFERENCE ON CLAYS AND CLAY MINERALS, New York, 1960. Proceedings... New York, Pergamon, 1960. p.317-327.

MICHELON, C.J.; CARLESSO, R.; PETRY, M.T.; DAVID, G. \& DALLA SANTA, C. Physical quality of irrigated soil of Rio Grande do Sul State-Brazil. Ci. Rural, 37:1308-1315, 2007.

MIRALLES, I.; ORTEGA, R.; ALMENDROS, G.; SÁNCHEZMARAÑ́N, M. \& SORIANO, M. Soil quality and organic carbon ratios in mountain agroecosystems of South-east Spain. Geoderma, 150:120-128, 2009.

MUNIZ, L.C.; MADARI, B.E.; TROVO, J.B.F.; CANTANHÊDE, I.S.L.; MACHADO, P.L.O.A.; COBUCCI, T. \& FRANÇA, A.F.S. Soil biological attributes in pastures of different ages in a crop-livestock integrated system. Pesq. Agropec. Bras., 46:1262-1268, 2011.

PARFITT, R.L. Allophane and imogolite: role in soil biogeochemical processes. Clay Miner., 44:135-155, 2009.

PERCIVAL, H.J.; PARFITT, R.L. \& SCOTT, N.A. Factors controlling soil carbon levels in New Zealand grasslands: is clay content important? Soil Sci. Soc. Am. J., 64:623$1630,2000$.

R CORE TEAM. R: A language and environment for statistical computing. Viena, R Project, 2011.

REICHERT, J.M.; REINERT, D.J. \& BRAIDA, J.A. Qualidade dos solos e sustentabilidade de sistemas agrícolas. R. Ci. Amb., 27:29-48, 2003.

REVELLE, W. Psych: Procedures for psychological, psychometric, and personality research. Viena, R Project, 2012. 282p.
SAMUEL-ROSA, A.; MIGUEL, P.; DALMOLIN, R.S.D. \& PEDRON, F.A. Uso da terra no Rebordo do Planalto do Rio Grande do Sul. Ci. Natura, 33:161-173, 2011.

SANTOS, H.G.; JACOMINE, P.K.T.; ANJOS, L.H.C.; OLIVEIRA, V.A.; OLIVEIRA, J.B.; COELHO, M.R.; LUMBRERAS, J.F. \& CUNHA, T.J.F., eds. Sistema brasileiro de classificação de solos. 2.ed. Rio de Janeiro, Embrapa Solos, 2006. 306p.

SCHIPPER, L.; PARFITT, R.L.; ROSS, C.; BAISDEN, W.; CLAYDON, J. \& FRASER, S. Gains and losses in C and $\mathrm{N}$ stocks of New Zealand pasture soils depend on land use. Agric. Ecosyst. Environ., 139:611-617, 2010.

SILVA, L.B.; DICK, D.P. \& INDA, A.V. Highland subtropical soils: Chemical attributes, content of organic matter and its resistance to chemical oxidation. Ci. Rural, 38:1167-1171, 2008.

SOIL SURVEY STAFF. Keys to soil taxonomy. Washington DC: USDA-NRCS, 2010. 346p.

STEIGER, J. Tests for comparing elements of a correlation matrix. Psychol. Bull., 87:245-251, 1980.

TAN, K.H. Principles of soil chemistry. 4.ed. Boca Raton, CRC Press, 2010. 362p.

TEDESCO, M.J.; GIANELLO, C.; BISSANI, C.A.; BOHNEN, H. \& VOLKWEISS, S.J. Analysis of soil, plants and other materials. Porto Alegre, Universidade Federal do Rio Grande do Sul, 1995. 174p.

WEBSTER, R. Statistics to support soil research and their presentation. Eur. J. Soil Sci., 52:331-340, 2001.

WEBSTER, R. Analysis of variance, inference, multiple comparisons and sampling effects in soil research. Eur. J. Soil Sci., 58:74-82, 2007.

WICKHAM, H. ggplot2: Elegant graphics for data analysis. New York, Springer, 2009. 212p.

YEOMANS, J.C. \& BREMNER, J.M. A rapid and precise method for routine determination of organic carbon in soil. Commun. Soil Sci. Plant Anal., 19:1467-1476, 1988. 